\title{
LEXICON
}

\section{PARTICIPLE AS SEEN IN THE JAKARTA POST HEADINGS}

\author{
Dwiana Marcheni Arumningtyas
}

\section{INTISARI}

Penelitian ini mendiskusikan penggunaan participle seperti tampak pada judul-judul artikel di koran The Jakarta Post. The Jakarta Post dianggap sebagai salah satu perusahaan koran yang representative untuk diteliti, khususnya bagi pembelajar bahasa Inggris selain penutur asli, karena sebagian besar ditulis oleh jurnalis Indonesia menggunakan bahasa Inggris berstandar baik. Data penelitian ini diambil dari The Jakarta Post edisi tanggal 6 September sampai 6 Oktober 2012.Judul yang ada dikelaskan berdasarkan jenis participle yang dikandungnya. Kemudian data dianalisa berdasarkan konteks untuk mengetahui arti dibalik penggunaan participle. Terakhir, penelitian ini membahas frekuensi penggunaan participle pada The Jakarta Post yang mungkin merefleksikan kecenderungan penulis Indonesia dalam mengekspresikan gagasannya dengan pengantar bahasa Inggris. Hasil dari penelitian ini adalah lima pola penggunaan present participle, enam tipe penggunaan past participle, makna dibaliknya, serta frekuensi penggunaannya.

Kata kunci: participle, judul, The Jakarta Post

\begin{abstract}
This paper discusses the usage of participle as seen in The Jakarta Post Headings. The Jakarta Post is considered as a representative newspaper especially for Non Native English Language Learners for it is mostly written by Indonesian journalists using good standard of English. The data of this research are taken from The Jakarta Post edition September 6 until October 6, 2012. The headings are classified based on the type of participle they contained. Afterwards, they are analyzed based on their context in order to figure out the meaning they might contain. Lastly, this paper talks about the prevalence of the participle in The Jakarta Post headings which may reflect the preference of participles used by Indonesian authors in expressing their idea in English. As the result, this paper points out the 5 patterns of present
\end{abstract}


participle, and 6 patterns of past participle used in The Jakarta Post, their meaning, and their frequency.

Keywords: participle, heading, The Jakarta Post

\section{INTRODUCTION}

Heading is one of the ultimate features in newspapers as people may be attracted to read the whole article by reading the heading. Linguistically, heading is considered as a phrase or a sentence. Heading, however, has some exceptions in its composing because it has some specific rules of its own in term of attractiveness and comprehension. In the other words, the heading writers will always try to make their headings interesting, yet understandable.

Using participles is one of grammatical tricks to compose an interesting heading. Participle is a word formed from a verb and used as an adjective (Warriner, 1958: 65). The participle acts as both a verb and an adjective. Therefore, it is a 'verbal adjective'. Furthermore, it has two forms, namely present participle (-ing) and past participle (-ed). Both of them have unique quality since within a clause, they do not depend on the subject as the usual verb does, i.e in non finite clause (Leech and Starvik, 1979: 213). Non-finite clause can be constructed without a subject, for instance: Entering the house, he tripped over the welcome mat (present participle); covered with confusion, she hurriedly left the room (past participle).

Since one may need a comprehensive knowledge about participles especially when it is used in headings, the researcher found it interesting to observe the usage of participle in an English language Newspaper. As this paper is sold in
Indonesia, which is occupied generally by Non Native English Learners, a daily newspaper which is mostly written by Indonesian people is chosen, namely The Jakarta Post.

More specifically, there are three interesting points of participle in headings to discuss. Firstly, its form and function. Secondly, the meaning contained beneath the usage of participle is also interesting. The point is to differentiate these two meanings caused by the same structure.

Thirdly, this paper is engaged in the frequency of the participle usage within the headings. It supports the reason of choosing The Jakarta Post as the data source. Because most of the writers of The Jakarta Post are Indonesians, it can be reflected by the result of this research that the Indonesian writers may have certain preference in using participle in their headings.

After all, the researcher believes that by understanding the concept of participle in headings, one may find it easier to understand the topic being talked in the article.

\section{PREVIOUS STUDY}

The researcher has found four researches in analyzing newspapers which are done prior to this one. The closest one is an analysis of the Jakarta Post headings patterns (Fuat, 2011). This research, which is done by an English Department undergraduate student, focused on the patterns of The Jakarta Post headings. It figures out the structural patterns (the syntactic structures) frequently used by The Jakarta Post in writing headings and also the preference of The Jakarta Post in 
applying the patterns to different kinds of journalistic writings: news, feature, and article. The method used in this paper is listing the headings of 18 editions of The Jakarta Post in February 2011. They were, then, analyzed using the theory of formal and functional syntax, including the transformation processes: deletion, permutation, and substitution process. It turned out that there are five classes considering the number of units and the structure used. After all, although the subject of this research is quite close to the subject of this paper, this current paper turns into more specific field of verbal construction to dig deeper into the heading writing.

\section{Rules of Writing Headings}

Heading is the subject of a section of a speech or piece of writing. (Oxford

Advanced Learners Dictionary, 2010).

1. The heading should answer as many W's, i.e. what, who, where, and why, as possible in the heading without making the heading appear kilometric. Avoid to mention 'when' in the heading (Radke, accessed on October 10, 2012)

2. The heading should not state something that is not included in the story.

3. Positive headings are preferable to negative ones.

4. Use a verb, expressed or implied, in main heading and sub heading.

To grab the readers' attention, the writer may make his heading into main and sub heading. The main heading is usually in bigger and bold font, while the sub one is smaller, less bold, yet still easy to read (mrfire.com, accessed on January 15, 2013).

5. The active verb is preferred to the passive verb, except in the instance that the event is more important than the doer.

Examples:
(1) GMA opens Palaro 2010 (using active verb).

(2) Agro industrial fair opened (using passive verb).

6. Delete article like a, an, the, and all forms of verb of being.

7. Use the present tense even for past stories, and the infinite form for future events.

8. Write numbers in figures or spell them out depending upon the allotted space for headings.

9. Use the comma (,), the punctuation mark, instead of the conjunction and in headings.

10. Write the position of a general word to identify a person, place, or thing that is not popular or common.

11. Avoid the passive form of the verb 'be' (Radke, 2012: slide 6)

\section{The Use of Present Participle (-ing form)}

\section{A. As an adjective}

Present participle (-ing form) are quite generally used to modify nouns. They occupy the same position as ordinary adjectives, or they are usually called verbal adjectives. (Praninskas, 1959:189). There are three positions which present participle can occupy to modify noun, namely:

a. After the verb be: (3)Errors in punctuation areconfusing. In other words, present participle here is to form the continuous tense.

$b$. Before the noun to be modified: (4) Visitingstudents need practice in conversation forms.

c. After the noun to be modified: (5) I like my teasteaming.

(Thomson and Martinet, 1979: 240)

\section{B. After verbs of sensation}

The basic verbs of the senses: see, hear, feel, smell, and the verbs listen (to), notice, watch and find can be followed by 
object + present participle (Thomson, Martinet, 1979: 239).

Examples:

(6) I see him passing my house every day.

(7) I heard her booking tickets.

\section{Replace a sentence or main clause}

When two actions by the same subject occur simultaneously it is usually possible to express one of them by a present participle. The participle can be before or after the finite verb:

(8) He rode away. He whistled as he went.

$=$ He rode away whistling. (present participle after the finite verb)

(9) He holds the rope with one hand and stretches out the other to the boy in the water

$=$ Holding the rope with one hand, he stretches out the other to the boy in the water. (present participle before the finite verb)

\section{Replace a subordinate clause}

The present participle can replace as/since/because + subject + verb, i.e. it can help to explain the action which follows, for instance:

(10) Knowing that he wouldn't be able to buy food on his journey he took large supplies with him.

$=$ As he knew that he wouldn't be able to buy food on his journey, he took large supplies with him.

\section{The Use of Past Participle (-ed)}

\section{A. As an adjective}

Like the present participle, the past participle is also frequently used as modifiers of noun or as an adjective. As a modifier, it modifies a noun (subject, object, or complement). For instance, within sentence (11) 'They are confused students', the past participle 'confused' functions as a modifier of a complement. (Azar, 1989: 144)

\section{B. As the verbal phrase to form the perfect tenses and the passive voice}

As the verbal phrase, past participle is used to show that the business or process is finished (Praninskas, 1959:251). It is often found in perfect tenses:

(12) We havelearned.

(13) He had solved.

On the other hand, past participle can also be used to compose passive voice with a form of be (Leech, 1979:244):

(14) She was injured in an accident.

(15) She was hidden by the kidnappers.

\section{Replace a sentence or main clause}

The past participle can replace a subject + passive verb just as the present participle can replace subject + active verb: (16) She enters. She is accompanied by her mother.

$$
\text { = She enters, accompanied by }
$$
her mother.

(17) The bridge had been weakened by successive storms and was no longer safe.

$=$ Weakened by successive storms, the bridge was no longer safe. 


\section{THE STUDY}

\section{THE PATTERNS OF PARTICIPLE IN THE JAKARTA POST HEADINGS}

There are 241 headings containing present participle, 337 headings containing past participle, and 4 headings among them are containing both present and past participle. Totally, the researcher analyzed 574 headings.

\section{Patterns of present participle}

Several patterns of present participle which are found are:

\section{Pattern I}

The first pattern of present participle in The Jakarta Post headings edition September 6 until October 6 is structured: Noun + be/ modal auxiliary $+\mathrm{V}$-ing.

Examples:

(18)

WB: Palestenian fiscal crisis $\frac{\text { is }}{\text { Noun phrase }}$ be/modal aux $\frac{\text { deepening }}{\mathrm{V} \text {-ing }}$

(Table 1.1 line 3)

This heading starts with a noun phrase which functions as the subject of the clause. The headword of this noun phrase is the word 'crisis'. The auxiliary verb comes after the noun phrase is in accordance with the headword. Therefore, the auxiliary verb used here is 'is'. A word following the auxiliary verb is a form of present participle. Syntactically, the present participle here impacts the meaning of the action done by the subject in term of progression. In other words, the present participle in this heading functions as a part of progressive aspect.

This pattern is very rare, because one of the rule in writing heading is that the writer have to 'delete article like a, an, the, and all forms of verb of being.' The researcher found that the verb 'be' is merely in quotation headings. There are only eight headings using this pattern of present participle. It shows that the usage of present participle together with auxiliary verb may not be very effective for headings.

Below are some other examples:

(19) The great chestnut trees of Europe are dying ( Table 1.1 line 1)

(20) Thai man was raising 6 tigers on rooftop (Table 1.1 line 2)

(21) Red line is fast approaching(Table 1.1 line 8)

\section{Pattern II}

\section{Structure: Article/ determiner + V-ing + Noun phrase}

Example:

(22)The surprising beauty of Arab democrac

(Table 1.2 line 1)

In this example, the word 'surprising' is a present participle within a noun phrase with the head 'beauty of Arab democracy'. It is seen that the -ing verb here is modifying the noun comes after, or, in the other words this heading states that 'the beauty of Arab democracy is surprising'. Therefore, we can conclude that this present participle function as an adjective.

More examples of this pattern are:

(23) L'Oreal Indonesia's glowing growth inspires investment (Table 1.2 line 2)

(24) China media comments on missing $\mathrm{Xi}$ as rumors fly (Table 1.2 line 8)

(25) Retiring Darwati reaches 7, as E. Java rules (Table 1.2 line 12)

There are 59 other tokens similar to this pattern.

\section{Pattern III}

Structure: Noun + V-ing + Noun (+Adverb) 
Example: (Table 1.3 line 1)

In this example, the first word 'North Korea' is a noun phrase. The word 'convening' is a verb phrase in the form of present participle. The next word is a noun 'parliament'. Looking at this heading, we can simply say that something is missing here. Since the noun at the beginning of the heading may function as the subject of the clause, with the verb 'convening' comes from the word 'convene', transitive verb, and noun 'parliament' as the clause object, this clause may miss the auxiliary verb. Therefore, the researcher assumed that the auxiliary verb 'is' here is omitted in term of economy reason.

Moreover, it is also stated in one of heading writing rules 'to delete all verbs of being'. Besides, it is very likely that the writer makes this kind of headings to catch the readers' attention toward its unusual structure.

According to the investigation, 64 tokens are similar to this pattern as well. Some of them are:

(27) Antitrust watchdog probing Samsung (Table 1.3 line 5)

(28) Obama foreign policy now looking dimmer (Table 1.3 line 27 )

(29) A rose revolution losing its bloom (Table 1.3 line 38)

\section{Pattern IV}

\section{Clause}

Structure: V-ing + Noun phrase/

Example:

(30) Though hurting, miner $\frac{\text { declines }}{\text { Conj }} \frac{\text { billion-dollar bid }}{\text { V-ing Serb }}$

(Table 1.4 line 84)

Clause

This heading has a Verb-ing (present participle) before a clause. It shows that the verb (present participle) here refers to the subject of the clause comes after it. for $2^{\text {nd }}$ tinseemingly, the present participle in this heading is formed in order to make the sentence shorter, in this case the writer deletes the same subject within two clauses. In other words, we may say that the former sentence is, 'Though miner hurts, miner declines billion-dollar bid'.

Below are some more examples of this pattern:

(31) Fires engulf Pakistan factories, killing 314 workers (Table 1.4 line 29)

(32) Facing anti-malaria nets, mosquitoes alter habits: study (Table 1.4line 47)

(33) RI executives take more trips, but spending drops (Table 1.4 line 65)

Another 96 tokens similar to this pattern are found among the data.

\section{Pattern V}

Structure: V-ing within a noun phrase (after noun be modified) + verb + adverb

\section{Example:}

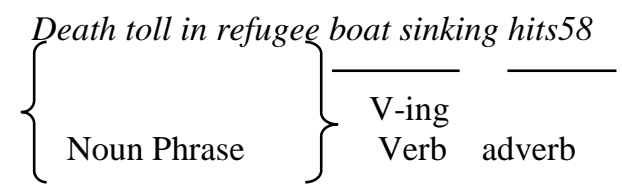

In this heading, 'Death toll in refugee boat sinking' is a noun phrase which functions as the subject of the clause. Within the noun phrase, the word 'toll' is the headword. Later, the word 'hits' is the finite verb, as it is affected by the subject. In this pattern, thus, we can see that the present participle is not working as a progressive verb with deleted auxiliary as we have seen in pattern III. Meanwhile, ' 58 ' means fifty eight people as the victim in the circumstance.

The word 'sinking' within the noun phrase gives extra information yet it is simplified, so that the noun phrase actually is 'death toll in a refugee boat which is sinking '. This present participle, then, 
functions as a post modifier in noun phrase.

There are 11 out of 222 tokens having this pattern of present participle. Some of them can be seen as follows:

(35) Syrian rebels take third border crossing to Turkey (Table 1.4 line 4)

(36) US stops 20 Iran officials attending UN assembly (Table 1.4 line 6)

(37) Fauzi spends last days in office bidding farewell (Table A.4 line 10)

\section{Patterns of past participle}

From the data, researcher found that there are several patterns of past participle usage as seen in The Jakarta Post headings in one month editions, they are:

\section{Pattern I}

Structure:

Noun (+ Modal Auxiliary) + Auxiliary verb + V3/ past participle

Example:

(38)

Curriculum should be improved (Table 2.1 line 1)

Noun

Modal Aux To be V3

We recognize this pattern as a pattern of passive voice. The past participle here functions as to make the noun mentioned before to be the victim. In writing headings, it will be better if we state something in active voice, since the agent may be unknown or unimportant. Therefore, the agent is not mentioned in this heading.

22 tokens are found similar to this pattern, such as:

(39) Fauzi graft allegations must be investigated: Analysts (Table 2.1 line 2)

(40) Sanitation target may not be achieved (Table 2.1 line 10)

(41) We shall not be moved (Table 2.1 line 4)

\section{Pattern II}

Structure: V3 + Noun

Example:

$\frac{(42)}{\text { Noun phrase }} \frac{\text { NorthKorea rips Chinese }}{\text { Verb Noun phrase }} \frac{\text { company }}{\text { Prep }} \frac{\text { in }}{\text { V3 }} \stackrel{\text { Noun }}{\text {. }}$

(Table 2.2 line 4)

In this pattern, 'in failed deal' is a noun phrase which functions as an adverb and with 'deal' as the headword. The past participle within this adverb modifies the noun after it. In other words, it has similar function as adjective. Therefore, participles are also known as adjectival verb.

Some more examples of this pattern are:

(43) Japanese govt agrees deal to buy disputed islands (Table 2.2 line 3)

(44) Disgraced Korean shuttlers have domestic bans lifted (Table 2.2 line 6)

(45) The hidden splendor of Nusakambangan(Table 2.2 line 10) The researcher totally found 78 tokens using this pattern of past participle.

\section{Pattern III}

Structure: Noun + V3 + Noun

Example:

(46) Yogyakarta Police reported to Ombudsman

Noun Verb Preposition Noun

(Table 2.3 line 1)

This heading has 'Yogyakarta Police' functions as the subject of the clause or sentence, the verb 'reported' as the action and the phrase 'to Ombudsman' as the adjunct. Looking at this heading, we may simply think that there is nothing unusual. The verb 'reported' may be the past verb of 'report'. Moreover, the word 'report' can be either transitive or 
intransitive verb. Yet, we may change our opinion about this kind of verb -ed is the past form when we look at the heading below:

(47) Police criticized over budget spending(Table 2.3 line 5)

The verb 'criticize' is transitive, so it needs object behind it. However, we could not see the object after 'criticize'. Therefore, the researcher assumed that in these two headings, the verbs do not belong to the past form, but it is a participle one, in a way that the auxiliary verb 'be' here is deleted. It may occur in terms of economical rule of writing headings as it is applied in the using of present participle above.

Besides, this assumption also suits a rule in writing heading that either the action happens in past or in present; the verb form should be in present form.

Some more examples of this pattern are:

(48) Golkar lawmaker detained in Koran scandal (Table 2.3 line 11)

(49) Ronggowasito honored with Bintang Mahaputera Medal (Table 2.3 line 21)

(50) Bureaucracy divided on new fuel scheme (Table 2.3 line 27)

Based on the data analysis, there are 220 headings using this pattern of past participle, two them are using past participle pattern 2 as well. They are tokens in Table 2.3 line 96, (51) Improved diagnosis skills needed to better tackle diabetes, and 216, (52) Endangered turtle returned to Cambodia. Nevertheless, this pattern has the largest number among the other patterns.

\section{Pattern IV} noun

Structure: V3 + Noun phrase/ Example:

(53) Grilled over construction fiasco, PON boss loses $\frac{\text { cool }}{\text { Verb Phrase }} \frac{\text { Verb }}{\text { Noun }}$
(Table 2.4 line 1)

We can see that in this heading, the Verb Phrase in the beginning of the heading forms a non-finite clause whose verb element is a non-finite verb phrase. Like the present participle which performs the same, it usually can be constructed without a subject as the subject comes after this clause. In this case, the subject is the subject of the next clause, 'PON boss', as the closest noun after the Verb Phrase acts as the object. In addition, this pattern may evoke dangling participle if the past participle used in the beginning of the sentence does not fit the subject it modifies behind.

Yet, the researcher thinks that heading writers sometimes do not show the subject which the past participle modifies. They may put the subject in the article below it. So they use past participle in this way in order to build readers' curiosity.

Other examples of this pattern are:

(54) Born to dance (Table 2.4 line 2)

(55) United, Liverpool have plenty to prove (Table 2.4 line 3 )

(56) Addicted to mockery, incitement (Table 2.4 line 4)

There are only 3 more tokens applying this pattern. This reflects that this pattern might not be preferable for the writer, likely because it shows minimum information in a heading

\section{Pattern V}

Structure: after the Noun to be modified/ replace a clause

Example:

(57) Orangutan dies after accidentally burned

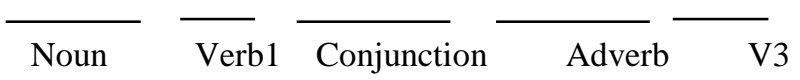


This example consists of one clause. The noun 'Orang utan' is the subject of the clause, the verb 'dies' obviously refers to the subject and functions as a predicate. Meanwhile, the phrase 'after accidentally burned' is the adverbial phrase to modify the verb 'dies'. This adjunct is called a phrase because it does not have subject on its own. It only has verb in the form of past participle. Nevertheless, to state the subject of this adverbial phrase, about what is accidentally burned, we should take a look to the closest noun. Since there is no noun before the past participle other than the word 'Orang utan', it can be seen that the past participle is modifying the subject of the clause before. Therefore, in such a way this heading may be 'Orangutan dies after it is accidentally burned'. Yet, it is very likely that in term of effectiveness, the same nouns as well as the verb following it are omitted.

The researcher only found 6 tokens which are similar to this pattern. Some other examples are:

(58) Nokia hopes pinned on latest Lumia smartphone (Table 2.5 line 2)

(59) EU facing a summit packed with pitfalls (Table B.5 line 4)

(60) The world's energy future relies on investment made today (Table 2.5 line 5)

Pattern VI

$$
\text { V3 Structure: Noun + certain Verb + }
$$

Example:

(61)

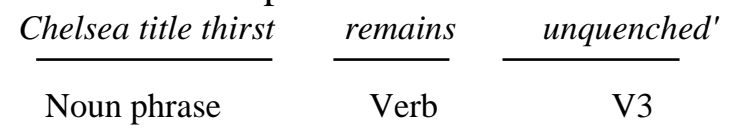

( 1 abie $L .0$ inne $L$ )

The past participle here, which is used to describe the subject or say what or who the subject is, is called a complement. Meanwhile, the verb is called a linking verb. The most common linking verb is be; others include become, come, grow, turn; keep, remain, stay; appear, look, seem, sound. In this example, the word 'remains' works as the linking verb, then. Thus, the past participle here is functioning as adjective which modifies the noun phrase 'Chelsea title thirst'. There are only 2 more headings with the same pattern as this one, they are:

(62) Impunity for the rich and famous leaves Thais outraged (Table 2.6 line 1)

(63) New terrorism suspects nabbed (Table 2.6 line 3 )

\section{Meaning of Present Participle}

\section{Pattern I: S + auxiliary verb (be) + Ving}

(1) WB: Palestinian fiscal crisis isdeepening (Table 1.1 line 3)

Using present participle this way means that the present participle is used to form the continuous tense. Therefore, the word 'deepening' here, which comes from the verb 'deepen' meaning 'to become worse' (Oxford Advanced Learners Dictionary, 2000:345), may mean that the 'Palestenian fiscal crisis is becoming worse' at the moment.

\section{Pattern II: Article/ determiner + V-ing + Noun}

(2)The surprising beauty of Arab democracy (Table 1.2 line 1)

The present participle is modifying the noun 'beauty of Arab democracy'. It comes from the word 'surprise' which means an event, a piece of news, etc. that is unexpected or that happens suddenly (Oxford Advanced Learners Dictionary, 2000:1362). Within this sentence, the present participle makes the sentence mean the 'beauty of Arab' is causing or having the effect of surprise. 


\section{Pattern III: Noun + V-ing + Noun (+Adverb)}

(64) North Korea convening parliament for $2^{\text {nd }}$ time. (Table 1.3 line 1 )

We may rarely find this structure in our daily language. Yet, we need to remember that in writing headings there is certain rule which disables the use of to be in order to make this heading compact and attractive as well. Thus, it is very likely that there is actually a 'be' is after the noun 'North Korea' before the verb ing (convening), or in other words, it is assumed that this heading substantively uses present continuous tense.

Looking at the meaning of word 'convening' which comes from the word 'convene' meaning 'to arrange for people to come together for a formal meeting' (Oxford Advanced Learners Dictionary, 2000:286), it makes sense if the use of present participle here means that 'North Korea is in a process to arrange for people to come together to parliament for $2^{\text {nd }}$ time.'

Regarding the progressive aspect contained in this structure, there are two possible meanings beyond this token. First, 'North Korea is in a process to convene the parliament', or second, 'North Korea is going to convene the parliament'. Because the present progressive can also be used for future events resulting from a present plan, program, or arrangement, and this construction often suggests the near future (Leech and Svartvik, 1973: 72).

After reading the article below the heading, it will be clear that this heading means the second possibility. It is seen from the first sentence of the article, 'North Korea is planning an unusual second parliamentary session of the year...' Thus, it furthermore can be concluded that to know exactly the meaning beyond the heading, the readers need to read the article below.

\section{Pattern IV:V-ing + Noun phrase}

(65) Though hurting, miner declines billion-dollar bid (Table 1.4 line 84 )

The word 'hurting in this heading, which comes from the verb 'hurt, may mean 'feel mental pain or distress' (http://oxforddictionaries.com/definition/a merican_english/hurt?q=hurt). Structurally, this verb refers to the subject comes after it. In other words, the heading consists of two clauses which both have the same subject so that the writer deletes the first subject in the term of economy and change the infinite verb into present participle form.

Therefore, we may conclude that this kind of heading may mean that the subject is 'doing' or 'having' the action, while it is 'doing' the other one, in this case, 'though the miner hurts, he declines billion-dollar bid'.

\section{Pattern V:V-ing within a noun phrase (after noun to be modified) + verb + adverb}

(66) Death toll in refugee boat sinking hits58(Table 1.5 line 1)

Seeing this heading, researcher assumed that the verb 'sinking' is modifying the word 'boat', the closest noun. It may be clearer if this heading is explained through 'Death toll in refugee boat which is sinking hits 58', as present participle may replace a relative clause (Thomson and Martinet, 1980:243). In other words, the sentence may consist of two clauses; 'Death toll in refugee boat hits 58 ' and 'refugee boat sink/ is sinking'. Yet, they are merged.

More specifically, 'Death toll in refugee boat sinking' is a noun phrase with 'death toll' as the head. Death toll means 'the amount of damage or the number of deaths that are caused in a particular disaster' (Oxford Advanced Learners 
Dictionary, 2000: 1423). In this context, the disaster is 'refugee boat (which is) sinking'. 'Sinking' comes from the word 'sink' meaning 'to damage a boat or ship so that it goes below the surface of the sea.' In conclusion, the refugee boat was going below the surface of the sea and as the result, 58 persons became victims.

\section{Meaning of past participle}

\section{Pattern I: Noun (+ Modal Auxiliary) + Auxiliary verb + V3/ past participle}

Curriculum should be

This pattern seems familiar since it is usually used daily as passive voice. The passive voice is used in English when it is more convenient or interesting to stress the thing done than the doer of it, or when the doer is unknown (Thomson and Martinet, 1980: 255). Within this example, the things done or the victim is 'curriculum'. The word 'improve', meaning 'to make something/ somebody better than before' (Oxford Advanced Learners Dictionary, 2000: 682), in past participle form indicates that 'someone/ something (the agent) should make the curriculum better than before.' In conclusion, with this pattern, the past participle is needed to make the sentence passive.

\section{Pattern II: V3 + Noun}

(68) NorthKorea rips Chinese company in failed deal(Table 2.2 line 4)

In this sentence, the past participle lies in a noun phrase which functions as adverb. The past participle itself functions as an adjective modifying the head noun 'deal'. 'Failed' means 'not successful' (Oxford Advanced Learners Dictionary, 2000: 473). So that the 'deal' is not successful or seeing this way, this sentence may mean that 'North Korea rips Chinese company in a deal which is not successful.'

\section{Pattern III: Noun + V3 + Noun}

(69) Yogyakarta Police reported to Ombudsman(Table 2.3 line 1)

Past participle in this heading is between two nouns. At a glance, we may think that the word 'reported' here is the past form of the verb 'report'. Yet, considering one rule of writing heading stating that both action in present or in past is using present tense, we may come to an assumption that the word 'reported' here is the past participle of the verb 'report', and it is very likely that the auxiliary verb before (be) is omitted in order to fulfill another requirement of writing heading.

Based on those assumptions, this heading appears to be 'Yogyakarta police is/ was reported to Ombudsman'. Afterwards, it can be figured out that the meaning of this heading is 'someone / something gave/ gives information about Yogyakarta police to Ombudsman'.

\section{Pattern IV: V3 + Noun phrase/ noun}

\section{(70) Grilled over construction fiasco, PON bossloses cool(Table 2.4line 1)}

The past participle in this heading refers to the subject, 'PON boss'. It seems that the subject in the first clause is followed by passive form (auxiliary verb + past participle), so that the complete sentence might be ' $P O N$ boss is grilled over construction fiasco, PON boss loses cool.' Since the subjects of these two clauses are the same, it could be simplified by showing the past participle only in the first clause. The agent of the past participle will automatically address the subject of next clause.

More specifically, 'grilled' here likely means 'to ask somebody a lot of questions about their ideas, actions, etc.' (Oxford Advanced Learners Dictionary, 2000: 592). Regarding the explanation above, we 
can conclude that 'PON boss is ask a lot of questions about his/her actions over construction fiasco (so that) he loses cool.'

\section{Pattern V: after the Noun to be modified/ replace a clause}

(71) Orangutan dies afteraccidentally burned (Table 2.5 line 1)

In this pattern, past participle is replacing Subject and Passive verb as well. It differs from the previous pattern as it is structured in different position, not at the beginning of the sentence. Yet, past participle here still addresses the subject of the closest clause which is 'Orangutan'.

Semantically, this heading means that 'Orangutan dies after it is accidentally burned/ injured by the fire' (Oxford Advanced Learners Dictionary, 2000: 168).

\section{Pattern VI: Noun + linking Verb + V3}

(72) Chelsea title

thirstremains unquenched (Table 2.6 line 2)

It is seen from the heading that the verb 'remains' functions similarly as 'be', to link the subject with what or how it is. Therefore, the word 'unquenched' is modifying the subject. Semantically, 'remain' in this context means 'to be still in the same state or condition'. Meanwhile, 'unquenched' here means 'not to be satisfied/ not to drink so that you no longer feel thirsty' (Oxford Advanced Learners Dictionary, 2000: 1480). In conclusion, this statement means 'Chelsea title thirst is still not satisfied' or 'Chelsea is still in the condition of title thirst'.

The other linking verbs may mean variously. For instance, 'remain', 'keep, 'stay' may mean something static; but 'become', 'come', 'grow', and 'turn' (into) may describe process of change (Hewings, 1999: 52).

\section{Prevalence of Present Participle}

Based on the analysis, 241 tokens containing present participle are divided into 5 patterns. 8 out of 241 belong to pattern I (Noun (+modal auxiliary) + to be $+\mathrm{V}$-ing); 64 tokens belong to pattern II (article/ determiner + V-ing + Noun phrase); 48 tokens are structured Noun + $\mathrm{V}$-ing + Noun (+Adverb); 100 tokens belong to pattern IV ( $\mathrm{V}$-ing + Noun phrase/ Noun); and the rest of them, 12 tokens, are included in pattern $\mathrm{V}$ (V-ing after the noun to be modified + verb + adverb).

The significance of the prevalence of each pattern can be seen clearer from the chart below:

\section{Prevalence of Present Participle}

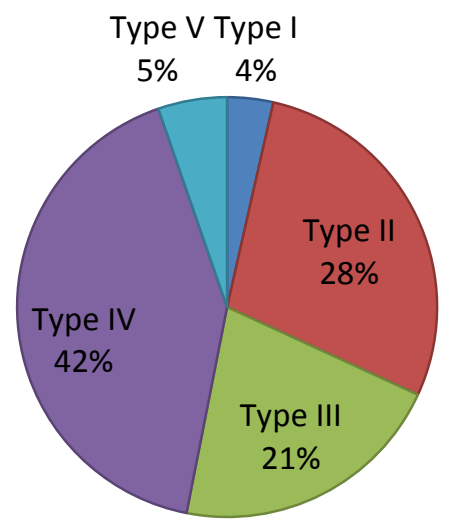

From the chart, we can see that the most dominant pattern of present participle usage is the fourth pattern, which the pattern is Pattern IV: V-ing + Noun phrase. This pattern shows the function of present participle in making non-finite participle phrase. The verb phrase in these headings modifies subject which is left behind the heading, or, the subject does not even appear in the heading. It seems like the heading writer wants to keep the readers' curiosity by doing this. So that the readers are pushed to read through the whole article if they want to figure out the subject. 


\section{Prevalence of Past Participle}

After classifying the data, it is found that past participle being used in The Jakarta Post could be divided into six patterns. The first pattern (modal auxiliary + be + V3) has 23 tokens; the second pattern (V3 + Noun) has 79 tokens; meanwhile, the highest number of tokens belongs to pattern III (Noun + V3 + Noun), 220 tokens; 7 tokens used past participle pattern IV (V3 + Noun phrase/ Noun); 7 tokens used pattern $\mathrm{V}$ (V3 after the noun to be modified/ replace a clause); and the rest of them, 3 tokens, belong to pattern VI (Noun + Linking Verb + V3).

The significance of the prevalence of each pattern can be seen as follows:

\section{Prevalence of Past Participle}

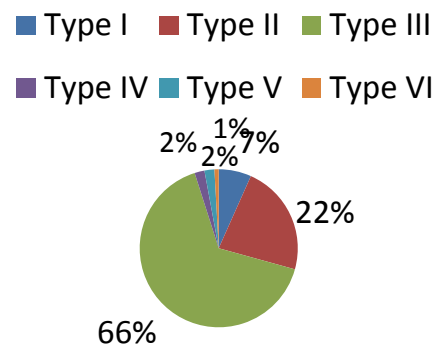

From the chart, it is obvious that the most dominant Past Participle usage in The Jakarta Post headings is the third pattern, which pattern is Noun $+\mathbf{V 3}+$ Noun. Through this pattern, it can be assumed that the auxiliary verb has been deleted for the sake of economy principle. This assumption is done after observing the context of the headings as well as considering the transitiveness of the verb. The readers are likely considered as already knowing that the noun comes before the Verb -ed is in passive voice. Therefore, the writers often omit the auxiliary verb 'be'.

From the prevalence of participle usage, it can be concluded that (1) Indonesia writers prefer using Past
Participle to using Present Participle, it might be affected by the reason that it is very common to communicate in passive voice in Bahasa Indonesia, (2) in using Present Participle, it is preferable for Indonesianwriters to express their idea into the pattern V-ing + noun phrase, which functions to make a non-finite clause. Grammatically, it can be seen that through this way, the writers would like to show the action or what is happening rather than mention the doer. On the other hand, (3) Indonesian writers tend to express their idea passively by using Past Participle pattern III, Noun + V3 + Noun. As Leech stated in his Textual Principle, this form might be considered as the most proportional, understandable, economical, and expressive.

\section{CONCLUSION}

This research concludes five patterns of present participle and six patterns of past participle as seen in The Jakarta Post headings. For the Present Participle, the usages are in the pattern (1) Noun (+ modal auxiliary) + be $+\mathrm{V}$-ing, so that it forms the progressive aspect; (2) Article/ determiner $+\mathrm{V}$-ing + Noun phrase, functioning as the modifier of the noun/ noun phrase; (3) Noun + V-ing + Noun, which shows that the progressive aspect exists but the 'be' was deleted; (4) V-ing + noun phrase, to state a non finite clause of present participle; (5) $\mathbf{V}$-ing after the noun to be modified + Verb + Adverb, functions as simplified relative clause, to give additional information about the noun.

Meanwhile, the first pattern of Past Participle is in the structure (1) Noun (+ Modal Auxiliary) + be + V3, functioning to compose passive voice; (2) V3 + Noun, modifying the noun after it; (3) Noun + V3 + Noun/ Adverb, showing that the 'to be' was deleted regarding the rules of writing heading; (4) V3 + Noun phrase / Noun, functioning in making non finite clause of past participle; (5) within a noun phrase/ 
after the noun to be modified, showing that it is such a simplified relative clause, which gives more information about the Noun; (6) Noun + Linking Verb + V3, functioning as a complement which describes the subject.

Secondly, the meaning of the participle as seen in The Jakarta Post headings vary from the adjective up to the part of non definite verbal phrases. For the present participle, the adjective meaning is showing that the noun it modifies is doing an action or in progress of an action. In non finite verbal clause, the use of present participle shows the active voice. Besides, it is also noticeable that an activity in progressive aspect shown by the present participle can mean more than one. Therefore, to determine the exact meaning of the participle in heading, it is important to know the context, by reading the article below the heading.

Meanwhile, for the past participle, it could work as a verbal adjectival as well. Yet, it shows that the noun or noun phrase it modifies becomes the victim of an action.

Furthermore, both present and past participle could be used to modify noun within a noun phrase. It has something to do with the conciseness that the writer has to fulfill as by using the present of past participle within a noun phrase, the writer could give extra information about the noun with short expression.

The highest prevalence of present participle usage is the use of present participle as a start of non-finite participle phrase. This pattern shows the present participle ability to make a heading more concise as when the heading is the nonfinite participle phrase, the subject could be not written in the heading, but just hidden in the article.

Meanwhile, the highest prevalence of past participle usage is in the deletion of auxiliary verb 'be' which comes before it. It is very likely that it is because 'to delete be' is the easiest way the writers can do to make their headings more compact but still deliver the complete message. Besides, it may happen as it is less confusing the readers compare to another deletion, such as the use of participle within the noun phrase.

\section{BIBLIOGRAPHY}

Allen, W. Stannard. Living English Structure for Schools. England: Longman, Green and Co., 1958

Azar, Betty Schrampfer. Understanding and Using English Grammar. New Jersey: Prentise-Hall, Inc. 1989

Boyer, James L. The Classification of Participles: A Statistical Study. Grace Theological Journal 5.2, 1984. p: $163-179$

Bungin, Burhan. Metodologi Penelitian Kualitatif. Jakarta: PT Raja Grafindo Persada. 2007

Burns, Anne. Collaborative Action Research for English Language Teachers. UK: Cambridge University Press, 1999. p:20

Childs, Larry G. "Present Participle Adjuncts in the Book of Norman". Journal of Book of Mormon Studies:volume-6, issue-1. Provo, Utah: Maxwell Institute., 1997. P: 24-38

Clanchy, John. Essay Writing for Students. $2^{\text {nd }}$ Ed. Australia: Addison Wesley Longman Australia, 1991

Curme, George O. English Grammar. New York: Barnes \& Noble, Inc., 1947

Fuat, Zaka. The Patterns of The Jakarta Post's Headings. Yogyakarta:Jurusan Inggris, Fakultas 
Ilmu Budaya, Universitas Gadjah Mada, 2011. Unpublished graduating paper for Sarjana Degree.

Hewings, Martin. Advanced Grammar in Use. Cambridge University Press: 1999

Johnson, A. and G. C. Thornley. Grammar and Idiom. London: Longman, Green and Co Ltd., 1948

Leech, Geoffrey and Jan Svartvik. A Communicative Grammar of English. UK: Longman Group Ltd, 1979

Leech, Geoffrey, et all. Longman Grammar of Spoken and Written English. $6^{\text {th }}$ Ed. United States: Longman, 2007

Maharani, Tisa. Reference Used as The Subclasses of Cohesive Devices in Online Newspaper Articles. Yogyakarta: Universitas Gadjah Mada, 2011. Unpublished graduating paper for Sarjana Degree.

Mulyati, Sri. Tipe-tipe judul berita surat kabar berbahasa Indonesia di Surakarta; kajian structural dan sosiolinguistik. Yogyakarta: Universitas Gadjah Mada, 2005. Unpublished graduating paper for Post graduate program.

Murphy, Raymond. Essential Grammar in Use. $2^{\text {nd }}$ Ed. Cambridge, England: Cambridge University Press, 1997

Myers, L. M. Guide to American English. $4^{\text {th }}$ Ed. New Jersey: Prentice-Hall, Inc, 1968

Nelson, Herbert B. English Essentials. Paterson, New Jersey: Littlefield, Adams \& Co. 1963
Nugraha, Cisya Dewantara. Thematic Devices Found in English Journalistic Texts. Yogyakarta:Jurusan Inggris, Fakultas Ilmu Budaya, Universitas Gadjah Mada, 2008. Unpublished graduating paper for Sarjana Degree.

Quirk, Randolph and Sidney Greenbaum. A University Grammar of English. England: Longman Group Ltd. 1973. P: 347

Teitelbaum, Harry. How To Write a Thesis. USA: Macmillan, 1994

Thomson, A. J. and A. V. Martinet. A Pratical English Grammar. $4^{\text {th }}$ Ed. London: Oxford University Press, 1986. P:105-115

Thomson, A. J. and A. V. Martinet. A Pratical English Grammar. $3^{\text {rd }}$ Ed. London: Oxford University Press, 1980. P:239-245, 255

Warriner, John E. English Grammar and Composition. New York: Harcourt, Brace \& World, Inc.

\section{Electronic sources:}

Artikel Sosiolinguistik. http://fahmirizkyanda.wordpress.com /2011/05/24/artikel-sosiolinguistik, accessed on December 21, 2012 Definition of Heading. http://oxforddictionaries.com/definiti on/english/heading. Accessed on October 17, 2012

Definition of

Pronominalization. http://www.collinsdictionary.com/dic tionary/english/pronominalization. accessed on March 12, 2013 
Lords. Rules on Heading Writing. http://www.servitokss.com/rules-onheading-writing. Accessed on October 10, 2012

Nordquist, Richard. Definition and Examples of Participle. http//:www.grammar.about.com. Accessed on April 24 ${ }^{\text {th }}, 2012$.

Radke, J \&E. Rules of Heading Writing. http://dlc.k12.ar.us. Accessed on October 2012.

Sugarman, Joe. Writing Power Headings.http://www.mrfire.com/arti cle-archives/guest-articles/joesugarman-secrets.html. accessed on January 15, 2013

Trenga, Bonnie. The Dangling Participle. www.inspectorsjournal.com.

Accessed on April 24 ${ }^{\text {th }}, 2012$. 